\title{
OPTIMALISASI PEMBANGUNAN PERUMAAHAN DENGAN MENGGUNAKAN METODE SIMPLEKS (STUDI KASUS PT. PARUJA KONSULTAMA)
}

\author{
Jusran 1 , A. Sahari2, Rais ${ }^{3}$ \\ ${ }^{1}$ Program Studi Matematika Jurusan Matematika FMIPA \\ Kampus Bumi Tadulako Tondo Palu \\ 1jusran_palasa@yahoo.com,2agus_sh@yahoo.com,3rais76_untad@yahoo.co.id
}

\begin{abstract}
Abstrak
Pertumbuhan jumlah penduduk yang terus meningkat berakibat pada kebutuhan akan rumah meningkat. Melihat keadaan ini banyak develover yang bermunculan untuk menyediakan rumah tempat tinggal. Develover biasanya lebih tertarik mengembangkan tipe rumah mewah karena profit marginnya lebih bagus dibandingkan jika mengembangkan tipe rumah sederhana. Namun disisi lain masyarakat lebih banyak membutuhkan tipe rumah sederhana sesuai kemampuan mereka. Kebutuhan masyarakat yang tinggi terhadap tipe rumah sederhana merupakan permasalahan bagi develover perumahan untuk menentukan jumlah masing-masing tipe rumah yang akan dibangun sehingga memenuhi aspek pasar. Dalam penelitian ini akan dibentuk model optimalisasi untuk menghitung berapa jumlah masing-masing tipe rumah yang akan dibangun menggunakan metode simpleks. Hasil analisis menunjukkan optimum jumlah tipe yang dibangun adalah rumah tipe 70 sebanyak 15 unit, rumah tipe 50 sebanyak 10 unit dan rumah tipe 45 sebanyak 30 unit. Keuntungan maksimal yang didapat sebesar Rp. 3.375.500.000.
\end{abstract}

Kata kunci $\quad$ : Optimalisasi, Tipe rumah, Metode Simpleks

\begin{abstract}
The human population increase make the necessary of residence increase too. Therefore, many of developer come to offer the residence. Developer usually more interest to develop the luxury home type because the profit margin's is better than the simplehome type. However, most people need the simple home type, appropriate with their finance ability. Because of that, appear a problem for the developer to determine the number of each home type. This research will construct the optimalization model to count the number of each home type that will build using the simplex method. The result showing that optimum number for home type 70 is 15 units, home type 50 is 10 untis and home type 45 is 30 units. The maximum profit is Rp.3.375.500.000.
\end{abstract}

Keywords : Optimalization, Home Type, Simplex Method 


\section{Pendahuluan}

Faktor yang mendorong sesorang untuk membeli rumah adalah ingin memiliki rumah untuk memenuhi kebutuhan akan tempat tinggal sebagai kebutuhan primer untuk kebutuhan rutinitas kehidupan sehari-hari, dalam lingkungan keluarga yang lengkap (Heinz Frick, 1999). Salah satu pengembang perumahan adalah PT. Paruja konsultama yang mengembangkan perumahan "Petobo Indah" yang pada saat ini masih dalam tahap pengembangan. Luas lahan yang akan dikembangkan $17.000 \mathrm{~m}^{2}$. Dalam pembangunan Perumahan Petoboh Indah di bangun 3 tipe rumah yaitu, tipe 70 dibangun diatas tanah seluas $160 \mathrm{~m}^{2}$, tipe 50 yang dibangun diatas tanah seluas 126 $\mathrm{m}^{2}$ dan tipe 45 yang dibangun diatas tanah seluas $112 \mathrm{~m}^{2}$. Program linier sebagai suatu teknik analisis kuantitatif, merupakan model matematika yang dapat diterapkan dalam pengambilan keputusan yang berhubungan dengan keterbatasan sumber daya demi mencapai tujuan terbaik yang telah ditentukan.

Dalam problem pembangunan perumahan, program linier dengan metode simpleks juga dapat digunakan untuk mendapatkan keuntungan maksimum. Dimana metode simpleks merupakan suatu metode yang secara sistematis dimulai dari suatu penyelesaian dasar yang fisibel ke pemecahan dasar fisibel lainnya, yang dilakukan berulang-ulang (iteratif) sehingga tercapai suatu penyelesaian optimum.

\section{Metode Penelitian}

Dalam penelitian ini data akan diolah secara manual dengan menggunakan Metode Simpleks untuk menentukan jumlah optimal masing-masing tipe rumah serta untuk mendapatkan keuntngan maksimal.

\section{Hasil dan Pembahasan}

Pengembang PT. Paruja Konsultama membangun 3 rumah sebagai alternatif bagi para konsumen untuk menentukan pilihan apakah mereka ingin rumah yang besar, yang sedang atau yang kecil. Ketiga tipe rumah yang dikembangkan termasuk dalam kategori rumah sederhana yang akan dibangung diatas tanah seluas $17.00 \mathrm{~m}^{2}$.

Adapun tipe rumah yang dikembangkan sebanyak tiga tipe rumah, yaitu :

1. Tipe 70 , mempunyai luas bangunan $70 \mathrm{~m}^{2}$ dibangun diatas tanah seluas $160 \mathrm{~m}^{2}$, dengan harga Rp.310.000.000 per unit

2. Tipe 50 , mempunyai luas bangunan $50 \mathrm{~m}^{2}$ dibangun diatas tanah seluas $126 \mathrm{~m}^{2}$, dengan harga Rp. 225.000 .000 perunit. 
3. Tipe 45 ,mempunyai luas bangunan $45 \mathrm{~m}^{2}$ dibangun diatas tanah seluas $112 \mathrm{~m}^{2}$, dengan harga Rp.215.000.000 per unit.

Tipe rumah dan deskripsi dari rumah dikembangkan seperti pada Tabel 1 berikut:

Tabel 1: Data Perumahan Petoboh Indah

\begin{tabular}{|c|l|l|l|l|l|}
\hline No & \multicolumn{1}{|c|}{ Uraian } & \multicolumn{1}{c|}{ Tipe 70 } & \multicolumn{1}{c|}{ Tipe 45 } & \multicolumn{1}{c|}{ Tipe 40 } & Batasan \\
\hline 1 & Luas Tanah & $160 M^{2}$ & $126 M^{2}$ & $112 M^{2}$ & $13.500 M^{2}$ \\
\hline 2 & Harga produksi & Rp. 223.500.000 & Rp. 168.750.000 & Rp. .161.250.000 & 10 Milyar \\
\hline 3 & Harga Jual & Rp. 310.000.000 & Rp. 225.000.000 & Rp. .215.000.000 & \\
\hline 4 & $\begin{array}{l}\text { Selisih harga jual - } \\
\text { harga produksi }\end{array}$ & Rp.77.500.000 & Rp.56.250.000 & Rp. 53.750.000 & \\
\hline
\end{tabular}

Sumber : PT. Paruja Kosultama Tahun 2013

\subsection{Formulasi fungsi dengan Metode Simpleks}

Masalah ini dapat diformulasikan sebagai berikut:

\subsubsection{Batasan Luas Lahan.}

Luas lahan yang dikembangkan $17.000 \mathrm{~m}^{2}$. Luas infrastruktur $3500 \mathrm{~m}^{2}$. Luas lahan yang tersedia untuk mendirikan bangunan rumah yang terdiri dari tiga tipe adalah maksimum seluas $13.500 \mathrm{~m}^{2}$.Formulasi fungsi kendala dengan batasan luas lahan yaitu:

$160 x_{1}+126 x_{2}+112 x_{3} \leq 13500$

menjadi

$160 x_{1}+126 x_{2}+112 x_{3}+s_{1}=13500$

dimana :

$x_{1}$ : Rumah Tipe 70

$x_{2}$ : Rumah Tipe 50

$x_{3}$ : Rumah Tipe 45

\subsubsection{Batasan Biaya Produksi.}

Dana yang tersedia untuk pembuatan rumah dengan 3 macam tipe maksimum 10 milyar rupiah.

Formulasi fungsi kendala dengan batasan biaya produksi yaitu :

$232 x_{1}+162 x_{2}+161 x_{3} \leq 10000$ 
menjadi

$232 x_{1}+162 x_{2}+161 x_{3} \quad+S_{2}=10000$

\subsubsection{Batasan Permintaan Pasar.}

Berdasrkan proporsi tipe penjualan (aspek pasar) proporsi tipe rumah diminati adalah tipe 70 berbanding tipe 50 dan berbanding tipe 45 adalah 3 berbanding 2 berbanding 6 .

Formulasi fungsi kendala dengan batasan proporsi sesuai aspek pasar adalah

$X_{1} \leq 1,5 X_{2}$

$3 X_{2} \leq X_{3}$

menjadi

$X_{1}-1,5 X_{2} \leq 0 \rightarrow X_{1}-1,5 X_{2}+\quad S_{3}=0$

$3 X_{2}-X_{3} \leq 0 \rightarrow 3 X_{2}-X_{3}+\quad S_{4}=0$

Formulasi fungsi tujuan $Z$ dengan memaksimalkan keuntungan adalah :

Maksimumkan $Z=77 x_{1}+56 x_{2}+54 x_{3}$

menjadi

$Z=77 x_{1}+56 x_{2}+53 x_{3}+0 S_{1}+0 s_{2}+0 s_{3}+0 s_{4}$

Keterangan :

77 = Laba rumah tipe 70 ( juta rupiah)

56 = Laba rumah tipe 50 (juta rupiah)

54 = Laba rumah tipe 45 ( juta rupiah)

\subsection{Penyelesaian dengan Metode Simpleks}

Berdasarkan formulasi diatas, dibentuk tabel simpleks sebagai berikut :

Tabel 2 : Iterasi I

\begin{tabular}{|c|c|c|c|c|c|c|c|c|c|c|}
\hline & $c_{j}$ & 78 & 56 & 54 & 0 & 0 & 0 & 0 & & \\
\hline $\bar{c}_{i}$ & $\bar{x}_{i}$ & $x_{1}$ & $x_{2}$ & $x_{3}$ & $s_{1}$ & $s_{2}$ & $s_{3}$ & $s_{4}$ & $b_{i}$ & $R_{i}$ \\
\hline 0 & $s_{1}$ & 160 & 126 & 112 & 1 & 0 & 0 & 0 & 13500 & 84,375 \\
\hline 0 & $s_{2}$ & 224 & 169 & 161 & 0 & 1 & 0 & 0 & 10000 & 44,643 \\
\hline 0 & $s_{3}$ & 1 & $-1,5$ & 0 & 0 & 0 & 1 & 0 & 0 & 0 \\
\hline 0 & $S_{4}$ & 0 & 3 & -1 & 0 & 0 & 0 & 1 & 0 & 0 \\
\hline & $z_{j}$ & 0 & 0 & 0 & 0 & 0 & 0 & 0 & 0 & \\
\hline & $z_{j}-c_{j}$ & -78 & -56 & -54 & 0 & 0 & 0 & 0 & 0 & \\
\hline
\end{tabular}

Pada tabel di atas memperlihatkan bahwa nilai negatif terkecil pada baris $z_{j}-z_{j}$ terletak pada kolom $x_{1}$, maka $x_{1}$ sebagai kolom kunci. Rasio pembagian nilai kanan dengan 
kolom kunci terkecil adalah 0 bersesuaian dengan baris $s_{3}$, maka $s_{3}$ sebagai baris kunci dan baris $s_{3}$ sebagai persamaan pivot. Angka kunci adalah 1.

Tabel 3: Iterasi II

\begin{tabular}{|c|c|c|c|c|c|c|c|c|c|c|}
\hline & $c_{j}$ & 78 & 56 & 54 & 0 & 0 & 0 & 0 & & \\
\hline $\bar{c}_{i}$ & & $x_{1}$ & $x_{2}$ & $x_{3}$ & $S_{1}$ & $S_{2}$ & $S_{3}$ & $S_{4}$ & $b_{i}$ & $R_{i}$ \\
\hline 0 & $s_{1}$ & 0 & 366 & 112 & 1 & 0 & -160 & 0 & 13500 & 36,885 \\
\hline 0 & $s_{2}$ & 0 & 505 & 161 & 0 & 1 & -224 & 0 & 10000 & 19,802 \\
\hline 77 & $x_{1}$ & 1 & $-1,5$ & 0 & 0 & 0 & 1 & 0 & 0 & 0,000 \\
\hline \multirow[t]{3}{*}{0} & $s_{4}$ & 0 & 3 & -1 & 0 & 0 & 0 & 1 & 0 & 0,000 \\
\hline & $z_{j}$ & 78 & -116 & 0 & 0 & 0 & 77 & 0 & 0 & \\
\hline & $z_{j}-c_{j}$ & 0 & -172 & -54 & 0 & 0 & 77 & 0 & 0 & \\
\hline
\end{tabular}

Berdasarkan tabel di atas maka kolom kunci adalah $x_{2}$ dan baris kunci adalah $s_{4}$. Hasil perhitungan iterasi selanjutnya sebagai berikut :

Tabel 4 : Iterasi III

\begin{tabular}{|c|c|c|c|c|c|c|c|c|c|c|}
\hline & $c_{j}$ & 78 & 56 & 54 & 0 & 0 & 0 & 0 & & \\
\hline $\bar{c}_{i}$ & $x_{j}$ & $x_{1}$ & $x_{2}$ & $x_{3}$ & $s_{1}$ & $s_{2}$ & $s_{3}$ & $s_{4}$ & $b_{i}$ & $R_{i}$ \\
\hline 0 & $s_{1}$ & 0 & 0 & 234 & 1 & 0 & -160 & -122 & 13500 & 57,692 \\
\hline 0 & $s_{2}$ & 0 & 0 & 329 & 0 & 1 & -224 & -168 & 10000 & 30,364 \\
\hline 77 & $x_{1}$ & 1 & 0 & $-0,5$ & 0 & 0 & 1 & 0,5 & 0 & 0 \\
\hline \multirow[t]{3}{*}{54} & $x_{4}$ & 0 & 1 & $-0,33$ & 0 & 0 & 0 & 0,33 & 0 & 0 \\
\hline & $z_{j}$ & 78 & 54 & $-56,5$ & 0 & 0 & 77 & 0 & 0 & \\
\hline & $z_{j}-c_{j}$ & 0 & 54 & -111 & 0 & 0 & 77 & 0 & 0 & \\
\hline
\end{tabular}


Tabel 5: Iterasi IV

\begin{tabular}{|c|c|c|c|c|c|c|c|c|c|}
\hline & $c_{j}$ & 78 & 56 & 54 & 0 & 0 & 0 & 0 & \\
\hline $\bar{c}_{i}$ & & $x_{1}$ & $x_{2}$ & $x_{3}$ & $s_{1}$ & $s_{2}$ & $s_{3}$ & $s_{4}$ & $b_{i}$ \\
\hline 0 & $s_{1}$ & 0 & 0 & 0 & 1 & $-0,71$ & $-0,842$ & $-2,395$ & 13500 \\
\hline 54 & $s_{2}$ & 0 & 0 & 1 & 0 & 0,003 & $-0,68$ & $-0,51$ & 30,364 \\
\hline 77 & $x_{1}$ & 1 & 0 & 0 & 0 & 0,0015 & 0,66 & 0,244 & 15,182 \\
\hline 56 & $x_{4}$ & 0 & 1 & 0 & 0 & 0,001 & $-0,227$ & 0,163 & 10,121 \\
\hline & $z_{j}$ & 77 & 56 & 54 & 0 & 0,34 & 1,389 & 0,346 & 3375,5 \\
\hline & $z_{j}-c_{j}$ & 0 & 0 & 0 & 0 & 0,34 & 1,389 & 0,346 & \\
\hline
\end{tabular}

\subsection{Pembahasan}

Metode simpleks merupakan suatu algoritma, karena prosesnya dilakukan secara iteratif. Setiap prosedur iteratif merupakan suatu prosedur sistematis diulang-ulang (iterasi) sampai hasil yang diinginkan tercapai sehingga penyelesaian pada iterasi tertentu adalah optimal.

Pada tabel iterasi I diatas memperlihatkan bahwa nilai negatif terbesar pada $z_{j}-c_{j}$ terletak pada kolom $x_{1}$, maka $x_{1}$ sebagai kolom kunci. Rasio pembagian nilai kanan dengan kolom kunci terkecil adalah 0 bersesuaian dengan baris $s_{3}$, maka $s_{3}$ sebagai baris kunci dan baris $s_{3}$ sebagai persamaan pivot. Angka kunci adalah 1, pada tabel iterasi II negatif terbesar pada $z_{j}-c_{j}$ terletak pada kolom $x_{2}$, maka $x_{2}$ sebagai kolom kunci. Rasio pembagian nilai kanan dengan kolom kunci terkecil adalah 0 bersesuaian dengan baris $s_{4}$, maka $s_{4}$ sebagai baris kunci dan baris $s_{4}$ sebagai persamaan pivot. Angka kunci adalah 3 , dan pada tabel iterasi III negatif teresar pada $z_{j}-c_{j}$ terletak pada kolom $x_{3}$, maka $x_{3}$ sebagai kolom kunci. Rasio pembagian nilai kanan dengan kolom kunci terkecil adalah 30,364 bersesuaian dengan baris $s_{2}$, maka $s_{2}$ sebagai baris kunci dan baris $s_{2}$ sebagai persamaan pivot. Angka kunci adalah 329.

Pada tabel Iterasi IV semua koefisien fungsi tujuan (nilai pada baris $z_{j}-c_{j}$ ) tidak ada yang bernilai negatif maka iterasi berhenti (tabel sudah optimal). Sehingga didpatkan jumlah pembangunan perumahan untuk masing-masing tipe rumah yang maksimal yakni tipe 70 sebanyak 15 unit, tipe 50 sebanyak 10 unit dan tipe 40 sebanyak 30 unit. Sehingga diperoleh keuntungan sebesar Rp. 3.375.5000.000,-- 
Hal menunjukan bahwa hasil optimalisasi denngan mengunakan Metode simpleks sangat membantu dalam perhitungan penentuah banyaknya jumlah masing-masing tipe rumah sehingga perlu menjadi perhatian developer dalam melakukan perencanaan pembangunan perumahan berikutnya.

\section{Kesimpulan}

Berdasarkan hasil penelitian dengan menggunakan metode simpleks pada pembangunan perumahan petobo indah adalah:

a. Jumlah optimal masing-masing tipe rumah yang bangunan yaitu tipe 70 sebanyak 15 unit, tipe 50 sebanyak 10 unit dan tipe 45 sebanyak 30

b. Keuntungan maksimal dari pembangunan perumahan yang dilakukan PT. Paruja Konsultama yaitu sebesar Rp. 3.375.500.000.

Hal menunjukan bahwa hasil optimalisasi denngan mengunakan Metode simpleks sangat membantu dalam perhitungan penentuah banyaknya jumlah masing-masing tipe rumah sehingga perlu menjadi perhatian developer dalam melakukan perencanaan pembangunan perumahan berikutnya.

\section{Daftar Pustaka}

[1]. Heinz .F. 1999. Teori perancangan kota dan penerapannya dalam Perancangan Kota Secara Terpadu, Yogyakarta: Kanisus 